\title{
SERUM VITAMIN A LEVELS IN CHILDREN DURING ACUTE GASTROENTERITIS AND LOWER RESPIRATORY TRACT INFECTION
}

\author{
Divyashree $S^{1}$, Suresh Kirupanandhan ${ }^{2}$
}

${ }^{1}$ Senior Resident, Department of Paediatrics, Indira Gandhi Institute of Child Health, Bangalore. ${ }^{2}$ Registrar, Vijaya Hospital, Vadapalani, Chennai.

\begin{tabular}{l}
\hline ABSTRACT \\
\hline OBJECTIVES \\
To know the sub-clinical deficiency of vitamin A in children during Acute Gastroenteritis and Lower Respiratory Tract Infections \\
and to compare serum Vitamin A levels of control group with WHO standard.
\end{tabular}
and to compare serum Vitamin A levels of control group with WHO standard.

\section{SUBJECTS}

25 cases - 25 cases of gastroenteritis and lower respiratory tract infection and 25 controls aged between 6 months and 6 years.

\section{STUDY DESIGN}

Case control study.

\section{METHODS}

History with detailed diet history, clinical examination, evaluation of nutritional status and signs of vitamin A deficiency, blood samples for estimation of vitamin A levels and routine haematological indices (Hb, TC, DC, PS study) and serum electrolytes in some cases of GE cases, chest X-ray PA view taken in some of the lower respiratory tract infection, other relevant investigations done pertaining to individual case.

\section{INCLUSION AND EXCLUSION CRITERIA}

Children with gastroenteritis and lower respiratory tract infections as cases and children with minor ailments (not affecting vitamin A levels) coming to OPD as controls, age between 6 months to 6 years will be included in the study. Children admitted in the hospital for diseases other than lower respiratory tract infections and gastroenteritis and children who are given vitamin A before admission will be excluded.

\section{RESULTS}

In this study vitamin A levels in 13 cases of GE and 12 cases of LRTI compared 25 controls. Incidence of GE constituted $25.6 \pm 8.2$ and LRTI constituted $25.5 \pm 8.3$ of all paediatric admissions. In the study group, $8 \%$ cases had reduced serum vitamin A levels and none in the control group. Serum vitamin A levels in infants were relatively low when compared with the older. There was also notable correlation between serum vitamin levels and dietary practices, nutritional status and socioeconomic status. There was significantly low levels of serum vitamin A in both gastroenteritis cases and lower respiratory tract infection cases compared with controls. For every one case of frank clinical deficiency of vitamin A, there was 6 subclinical cases.

\section{CONCLUSION}

Significant reduction in serum vitamin A levels in gastroenteritis cases and lower respiratory tract infection cases compared to controls. There was no significant number of cases with frank clinical signs of vitamin A deficiency, in spite of reduced levels of serum vitamin A. Therefore, the need for vitamin A supplementation in all gastroenteritis cases and lower respiratory tract infections.

\section{KEYWORDS}

Vitamin A, WHO Standard, Xerophthalmia, Gastroenteritis, Respiratory Infection.

HOW TO CITE THIS ARTICLE: Divyashree S, Kirupanandhan S. Serum vitamin A levels in children during acute gastroenteritis and lower respiratory tract infection. J. Evolution Med. Dent. Sci. 2016;5(69):4999-5002, DOI: 10.14260/jemds/2016/1135

\section{INTRODUCTION}

Vitamin A deficiency is a major public health problem in all developing countries reportedly affects five million Asian children.1,2 and about 3,30,000 children in India.3,4,5,6 and causing partial or total blindness among 60,000 to $1,84,500$ Indian children as per National Nutritional Survey 1993.7,8,9

Financial or Other, Competing Interest: None.

Submission 06-08-2016, Peer Review 20-08-2016,

Acceptance 22-08-2016, Published 29-08-2016.

Corresponding Author:

Divyashree $S$,

D/o N. Shanthappa,

No.9, Mallikarjuna Nilaya,

$4^{\text {th }}$ Cross, Maruthi Nagar,

Chandra Layout, 80 FT Road,

Bangalore-72.

E-mail: divyashree84@yahoo.com

DOI: $10.14260 /$ jemds/2016/1135
The morbidity and mortality rates were four times higher in Respiratory infection, Diarrhea and Measles if they had associated vitamin A deficiency. The morbidity and mortality rates in under 5 years children can be decreased by providing required amount of vitamin $A .10,11$

Hence, this study was undertaken to estimate the vitamin A level in children from 6 months to 6 years with lower respiratory tract infection and gastroenteritis.

\section{AIMS AND OBJECTIVES OF THE STUDY}

To estimate serum vitamin A levels in children aged 6 months to 6 years during Acute Gastroenteritis and Lower Respiratory Tract Infection.

1. To know the sub-clinical vitamin A deficiency in children during Acute Gastroenteritis and Lower Respiratory Tract Infections. 
2. To compare serum vitamin A levels of control group with WHO standard.

3. Hence, to know the necessity of vitamin A supplementation to children during Acute Gastroenteritis and Lower Respiratory Tract Infections.

\section{MATERIAL AND METHODS}

Source of DATA - Children in the age group from six months to 6 yrs. admitted to the paediatric medical wards of Sree Balaji Medical College and Hospital, Chennai.

A total of 25 cases and 25 controls were included in the study from October 2010 to October 2011.

The data was collected by direct questioning and examination of study group children. Funding for estimation of Vitamin A levels is borne by the researcher.

\section{Sample Size - 25 Cases and 25 Controls}

For each case one control is taken in the same age group of children attending Immunization clinic and Paediatric OPD with minor ailments (conditions not affecting vitamin A levels).

\section{Sampling Procedure}

Cases were taken in children between 6 months to 6 years of age presenting with Gastroenteritis and Lower respiratory tract infection and controls were taken in the same age group with minor ailments after fulfilling the inclusion and exclusion criteria were included in the study.

\section{Inclusion Criteria \\ Cases}

- Children with Gastroenteritis and Lower respiratory tract infections were included in the study.

- Age between 6 months to 6 yrs.

Controls

- Children with minor ailments attending to OPD and children who come for vaccination were included in the study.

- Age between 6 months to 6 yrs.

\section{Exclusion Criteria}

Cases

- Children admitted in the hospital for diseases other than Lower respiratory tract infections and Gastroenteritis are excluded.

- Children above 6 yrs. and below 6 months of age presenting with LRTI and GE are excluded in the study.

- Children with Gastroenteritis and Lower respiratory tract infection, who were given vitamin A before admission were excluded.

\section{Controls}

- Children attending OPD with GE and Lower respiratory infections are excluded.

- Children below 6 months and above 6 yrs. attending OPD and immunization clinic were excluded and children administered vitamin A within 6 months interval.

\section{DATA COLLECTION}

\section{Procedure after Case Selection}

1. A detailed history including diet history was taken and clinical examination performed, an evaluation of nutritional status and signs of vitamin A deficiency was done.
2. Blood samples were collected for estimation of vitamin A levels and routine haematological indices and serum electrolytes in some of the GE and Chest X-ray PA view taken in some of the lower respiratory tract infection cases. Urine samples were collected in sterile bottle for microscopic examination in some cases.

3. Other relevant investigations done pertaining to individual case.

Procedure for taking Blood Sample for Estimation of Serum Vitamin A

After the admission, $5 \mathrm{~mL}$ of blood was drawn into a plain test tube and immediately submitted to the laboratory and once the serum was separated samples were sent for processing by High Pressure Liquid Chromatography System.

RESULTS AND ANALYSIS

Serum Vitamin A Status in Study Group and Control Group with WHO Standard (Table 1)

\begin{tabular}{|c|c|c|}
\hline $\begin{array}{c}\text { S. Vitamin } \\
\mathbf{A} \boldsymbol{\mu g} / \mathbf{d L}\end{array}$ & Study & Control \\
\hline$<10$ & $2(8 \%)$ & $0(0 \%)$ \\
\hline $10-19$ & $3(12 \%)$ & $0(0 \%)$ \\
\hline $20 \&$ Above & $20(80 \%)$ & $25(100 \%)$ \\
\hline Total & $\mathbf{2 5 ( 1 0 0 \% )}$ & $\mathbf{2 5 ( 1 0 0 \% )}$ \\
\hline & $\begin{array}{r}\text { Low levels of Serum Vitamin A is } \\
\text { significantly more in cases compared to } \\
\text { Inference }\end{array}$ & \multicolumn{2}{c|}{ controls with P=0.050* } \\
\hline \multicolumn{2}{|c|}{ Table 1: Shows the Vitamin A Status in Cases and } \\
Controls with Reference to WHO Standard
\end{tabular}

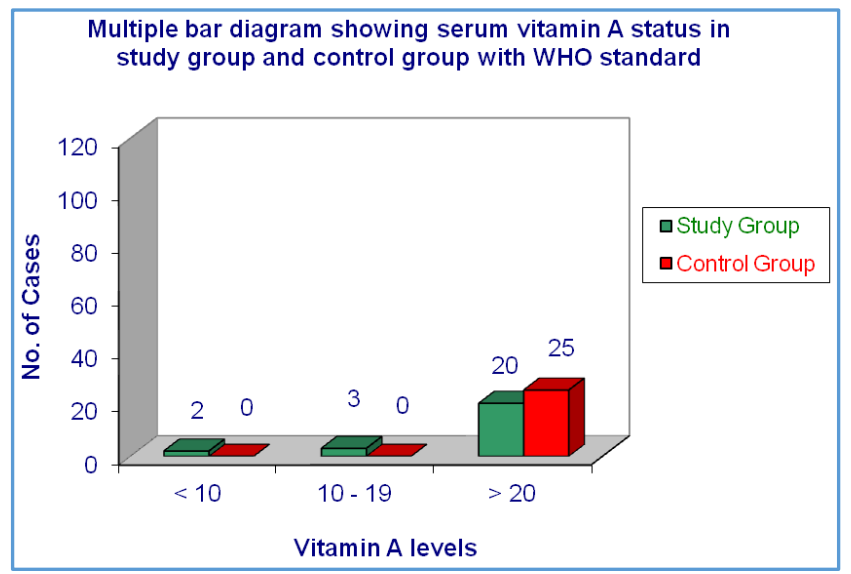

Serum Vitamin A Status in GE and LRTI Cases with WHO Standard (Table 2)

\begin{tabular}{|c|c|c|c|}
\hline \multirow{2}{*}{ Diseased State } & \multicolumn{3}{|c|}{ Serum Vitamin A ( $\mu \mathrm{g} / \mathbf{d L})$} \\
\cline { 2 - 4 } & $<\mathbf{1 0}$ & $\mathbf{1 0 - 1 9}$ & $\mathbf{2 0}$ \& Above \\
\hline GE $(\mathrm{n}=13)$ & $1(8 \%)$ & $2(15 \%)$ & $10(77 \%)$ \\
\hline LRTI $(\mathrm{n}=12)$ & $1(8 \%)$ & $1(8 \%)$ & $10(84 \%)$ \\
\hline $\begin{array}{c}\text { Table 2: Shows the Vitamin A Status in Gastroenteritis } \\
\text { and Lower Respiratory Tract Infection Cases }\end{array}$ \\
\hline
\end{tabular}


Serum Vitamin A Levels in Relation to Age in Study Group and Control Group (Table 3)

Age distribution comparison of Serum Vitamin A levels according to age in cases and control.

\begin{tabular}{|c|c|c|c|}
\hline \multirow{2}{*}{$\begin{array}{l}\text { Age in } \\
\text { Years }\end{array}$} & \multicolumn{2}{|c|}{ S. Vitamin A $\mu \mathrm{g} / \mathrm{dL}$} & \multirow{2}{*}{ P value } \\
\hline & Cases & Controls & \\
\hline$<1$ years & $33.25 \pm 6.17$ & $54.02 \pm 28.12$ & 0.108 \\
\hline $\begin{array}{c}1-2 \\
\text { years }\end{array}$ & $21.88 \pm 7.62$ & $65.95 \pm 27.21$ & $<0.001^{* *}$ \\
\hline $\begin{array}{c}2-4 \\
\text { years }\end{array}$ & $27.64 \pm 6.06$ & $49.46 \pm 20.35$ & $0.031^{*}$ \\
\hline $\begin{array}{c}4-6 \\
\text { years }\end{array}$ & $21.09 \pm 11.47$ & $55.20 \pm 2.55$ & $0.055+$ \\
\hline $\mathrm{P}$ value & $0.029^{*}$ & 0.594 & - \\
\hline \multicolumn{4}{|c|}{$\begin{array}{c}\text { Table 3: Shows the Serum Vitamin A Levels According to } \\
\text { Age Group Indicating that, Vitamin A Levels in Infants } \\
\text { are Low when Compared to Older Children }\end{array}$} \\
\hline
\end{tabular}

Serum Vitamin A Levels in Relation to Gender in Study and Control Group (Table 4)

\begin{tabular}{|c|c|c|c|}
\hline \multirow{2}{*}{ Gender } & \multicolumn{2}{|c|}{$\begin{array}{c}\text { S. Vitamin A (Mean + S.D. } \\
\mu \mathrm{g} / \mathrm{dL})\end{array}$} & \multirow{2}{*}{$P$ value } \\
\hline & $\begin{array}{c}\text { Study Group } \\
(n=25)\end{array}$ & $\begin{array}{c}\text { Control Group } \\
(n=25)\end{array}$ & \\
\hline Male & $25.62 \pm 9.78$ & $52.82 \pm 28.98$ & $<0.001^{* *}$ \\
\hline Female & $26.26 \pm 6.74$ & $63.31 \pm 18.85$ & $<0.001^{* *}$ \\
\hline P value & 0.855 & 0.298 & - \\
\hline \multicolumn{4}{|c|}{$\begin{array}{c}\text { Table 4: Shows the Decrease in Serum Vitamin A Levels } \\
\text { in Males Compared to Females in Study Group and } \\
\text { Control Group }\end{array}$} \\
\hline
\end{tabular}

Relation between Reduced Serum Vitamin A Levels and Xerophthalmic Changes in GE and LRTI Cases (Table 5)

\begin{tabular}{|c|c|c|}
\hline $\begin{array}{c}\text { Diseased } \\
\text { State }\end{array}$ & $\begin{array}{c}\text { Cases with Low } \\
\text { Stores of Vitamin A } \\
(<\mathbf{2 0} \boldsymbol{\mu} \mathbf{g} / \mathbf{d L})\end{array}$ & $\begin{array}{c}\text { Xerophthalmic } \\
\text { Changes }\end{array}$ \\
\hline $\mathrm{GE}(\mathrm{n}=13)$ & $3(23.1 \%)$ & $1(7.7 \%)$ \\
\hline $\mathrm{LRTI}(\mathrm{n}=12)$ & $2(16.7 \%)$ & $1(8.3 \%)$ \\
\hline \multicolumn{2}{|c|}{ Table 5: Shows Low Stores Vitamin A and } \\
Xerophthalmic Changes
\end{tabular}

Relation between Reduced Serum Vitamin A Levels and Xerophthalmic Changes in Study Group and Control Group (Table 6)

\begin{tabular}{|c|c|c|}
\hline Group & $\begin{array}{c}\text { Cases with Low } \\
\text { Stores of Vitamin A } \\
(<\mathbf{2 0} \boldsymbol{\mu g} / \mathbf{d L})\end{array}$ & $\begin{array}{c}\text { Xerophthalmic } \\
\text { Changes }\end{array}$ \\
\hline $\begin{array}{c}\text { Study } \\
(\mathrm{n}=25)\end{array}$ & $\begin{array}{c}5 \\
(\mathrm{n}=25)\end{array}$ & $\begin{array}{c}2 \\
(\mathrm{n}=5)\end{array}$ \\
\hline $\begin{array}{c}\text { Control } \\
(\mathrm{n}=25)\end{array}$ & 0 & 0 \\
\hline $\begin{array}{c}\text { Table 6: Shows } \mathbf{5} \text { Cases in the Study Group to have Low } \\
\text { Stores of Vitamin A Levels. Out of these 5 Study Group } \\
\text { Cases, Only 2 Cases showed Xerophthalmic Changes }\end{array}$ \\
\hline
\end{tabular}

Serum Vitamin A Levels in Cases and Controls (Table 7)

\begin{tabular}{|c|c|c|c|}
\hline S. Vitamin A & Cases & Controls & P Value \\
\hline Min-Max & $8.68-39.12$ & $23.50-106.50$ & \multirow{2}{*}{$\mathrm{t}=6.236$} \\
\cline { 1 - 3 } Mean \pm SD & $25.93 \pm 8.29$ & $58.27 \pm 24.73$ & $\mathrm{p}<0.001^{* *}$ \\
\hline 95\% CI & $22.50-29.35$ & $48.06-68.48$ & \\
\hline
\end{tabular}

\begin{tabular}{|c|c|c|c|c|}
\hline 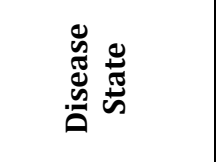 & 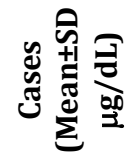 & 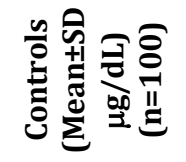 & $\stackrel{\vec{y}}{\stackrel{\vec{N}}{N}}$ & 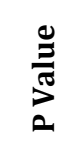 \\
\hline Gastroenteritis & $\begin{array}{c}25.6 \pm 8.2 \\
(n=13)\end{array}$ & $58.27 \pm 24.73$ & Significant & 0.001 \\
\hline $\begin{array}{l}\text { Lower } \\
\text { respiratory } \\
\text { tract infection }\end{array}$ & $\begin{array}{c}25.5 \pm 8.3 \\
(n=12)\end{array}$ & $58.27 \pm 24.73$ & Significant & 0.001 \\
\hline \multicolumn{5}{|c|}{$\begin{array}{c}\text { Table 7: Shows the Mean Serum Vitamin } \\
\text { A Levels in Cases and Controls }\end{array}$} \\
\hline
\end{tabular}

\section{DISCUSSION}

For the present study of 25 cases, 13 cases of Gastroenteritis and 12 cases of lower respiratory tract infection were chosen between the age group of 6 months to 6 years. Comparison of these 25 cases was made with 25 controls.

\section{Correlation with WHO Standard}

As per the WHO standard, in the study group 2 cases had less than $10 \mu \mathrm{g} / \mathrm{dL}$ of serum vitamin A indicating deficiency; 3 cases had $10-19 \mu \mathrm{g} / \mathrm{dL}$ indicating low stores and 20 cases had $>20$ $\mu \mathrm{g} / \mathrm{dL}$ indicating normal levels of serum vitamin A. All the control group children had $>20 \mu \mathrm{g} / \mathrm{dL}$ indicating normal serum vitamin A levels. In the present study, 8\% of GE and LRTI cases had lower levels of vitamin A. This reduced serum vitamin A levels is probably related to infections, which causes reduced intake and absorption of Vitamin A as well as increased utilisation in tissues and increased renal loss as suggested by Semba R. D. 12

\section{Correlation with Age}

In the present study, Vitamin A levels in the age group of 6 months to 2 years was lower than the other age groups in both study and control group. This can be explained by a preexisting low serum vitamin A levels in normal infants compared to normal children as seen in our control group. ${ }^{13}$

Relation between Reduced Serum Vitamin A Levels and Xerophthalmic Changes

Though subclinical vitamin A deficiency was present in $23.1 \%$ of GE cases and $16.7 \%$ LRTI cases, xerophthalmic changes were observed only in $7.7 \%$ of GE cases and $8.3 \%$ of LRTI cases. This shows the existence of subclinical vitamin A deficiency without any clinical evidence of vitamin A deficiency. The prevalence of subclinical vitamin A deficiency in India is in the range of 25 to 86 percent as reported by Reddy $\mathrm{V}$ et al (1989).14 Mehra S. Aneja et al (1994) ${ }^{15}$ and Laxmaiah A (2011). ${ }^{16}$

Serum Vitamin A Levels in Both Cases GE and LRTI and Controls

In our study, the mean serum vitamin A level in gastroenteritis cases was $25.6 \pm 8.2 \mu \mathrm{g} / \mathrm{dL}$ and mean vitamin A level in lower respiratory tract infection cases was $25.5 \pm 8.3 \mu \mathrm{g} / \mathrm{dL}$. In controls, the mean vitamin A levels was $58.27 \pm 24.73 \mu \mathrm{g} / \mathrm{dL}$. Serum vitamin A levels in both GE cases and LRTI cases were significantly lower than the control group. A study done by Kucukbay H. et al 17 in Malatya children with recurrent acute respiratory infections and diarrhoea was shown serum vitamin A level of $51.66 \pm 8.1 \mu \mathrm{g} / \mathrm{dL}$ in respiratory infections, $47.21 \pm 8.27 \mu \mathrm{g} / \mathrm{dL}$ in diarrhea cases and $58.14 \pm 9.07 \mu \mathrm{g} / \mathrm{dL}$ in 
controls. A study done by Velasquez-Melendez G. et al ${ }^{18}$ in children of Brazil with acute respiratory infection and diarrheal diseases was showing plasma vitamin A level (15.2 $\mu \mathrm{g} / \mathrm{dL}$ in both infection) lower than control group (18.8 $\mu \mathrm{g} / \mathrm{dL}$ ). A case control study done by Dudley L et al ${ }^{19}$ on vitamin A status in respiratory infection was showing mean (SD) vitamin A levels were 22.09 (7.27) $\mu \mathrm{g} / \mathrm{dL}$ for controls, 20.27 (11.11) $\mu \mathrm{g} / \mathrm{dL}$ for the mild cases and 13.79 (7.60) $\mu \mathrm{g} / \mathrm{dL}$ for severe cases. A study done by Hanekom WA et $\mathrm{al}^{20}$ in South African children with pulmonary tuberculosis was showing low plasma vitamin A levels (Mean 18.1 $\pm 10.3 \mu \mathrm{g} / \mathrm{dL}$, 62\% below normal).

A study done by Kassu A. ${ }^{21}$ in Ethiopia showed serum vitamin A levels (serum retinol $<20.05 \mu \mathrm{g} / \mathrm{dL}$ ) in $52.7 \%$ of diarrhoea patients among the total number of cases, and a study done in China by Qian L and Lu JR.22 showed that serum vitamin A levels in children with recurrent respiratory infections were significantly lower than controls $(33.23+/-6.3$ $\mu \mathrm{g} / \mathrm{dL}$ versus $44.6+/-3.4 \mu \mathrm{g} / \mathrm{dL} ; \mathrm{P}<0.05$ ). In comparison with other studies, our study also showed low levels of serum vitamin A in Gastroenteritis and Lower respiratory tract infection cases than in controls.

\section{CONCLUSION}

There is significant reduction in serum vitamin A levels in gastroenteritis cases and lower respiratory tract infection cases compared to controls. In spite of reduced levels of serum vitamin $A$, there is no significant number of cases with frank clinical signs of vitamin A deficiency. Hence, the need for vitamin A supplementation in all gastroenteritis cases and lower respiratory tract infections. All the controls in the study had normal serum vitamin A levels.

\section{REFERENCES}

1. Sommer A, Tarwotjo I, Hussaini G, et al. Incidence, prevalence and scale of blinding malnutrition. Lancet 1981;1(8235):1407-8.

2. Brown E, Akré J. Indicators for assessing vitamin A deficiency and their application in monitoring and evaluating intervention programmes. World Health Organization, Geneva 1996:66.

3. National Nutrition Monitoring Bureau. NNMB Reports. National Institute of Nutrition, Hyderabad 1979-2006.

4. Indian Council of Medical Research. Micronutrient Profile of Indian Population, New Delhi 2004.

5. Department of Women and Child Development. India Nutrition Profile. Government of India, New Delhi 1995-96.

6. Ministry of Family and Health Welfare. District Level Household Survey. Government of India, New Delhi 2002-03.

7. Shah PM. Strategies for prevention of malnutritional blindness in India: operational methodology, management, monitoring and cost/benefit. Report presented to the Royal Common Wealth Society for the blind, England 1978.
8. National Family Health Survey (NFHS-3): http://mohfw.nic.in/nfhsfactsheet.htm; last accessed on 24/09/07.

9. Report of district nutrition project. Indian Council of Medical Research 1999, NIPCCD: Situational Analysis of Children 1989:42.

10. Imdad AHK, Mayo-Wilson E, Yakoob MY, et al. Vitamin A supplementation for preventing morbidity and mortality in children six months to five years of age. Cochrane Database Syst Rev 2010;8(2):CD008524.

11. Biswas R, Biswas AB, Manna B, et al. Effect of vitamin A supplementation on diarrhea and acute respiratory tract infection in children. A double blind placebo controlled trial in a Calcutta slum community. Eur J Epidemiol 1994;10(1):57-61.

12. Semba RD. Vitamin A, immunity and infections. Clin Infec Dis 1994;19(3):489-99.

13. John CS, Lewis BA. Vitamin deficiencies and excess. Text book of paediatrics. $16^{\text {th }}$ ed. Chapter 44 . Behrman BE, Kleigman RM, Jenson HB. Singapore Harcourt Asia Pvt Ltd 2000:176-8.

14. Reddy V, Rao V, Arunjyothi, et al. Conjunctival impression cytology for assessment of vitamin A status. Am J Clin Nutr 1989;50(4):814-7.

15. Mehra S, Aneja S, Choudhary M. Vitamin A deficiency with acute diarrhea. J Diarrheal Dis Res 1994;12(2):125-8.

16. Laxmaiah A, Nair MK, Arlappa N, et al. Prevalence of ocular signs and subclinical vitamin A deficiency and its determinants among rural pre-school children in India. Public Health Nutr 2012;15(4):568-77.

17. Kucukbay H, Yakinlinc, Bay FZK, et al. Serum vitamin A and carotene levels in children with recurrent acute respiratory infection and diarrhea in Malatya. Journal of Tropical Pediatrics 1997;43(6):337-40.

18. Velasquez-Melendez G, Okani ET, Keirtsman B, et al. Plasma levels of vitamin A, carotenoids and retinal binding protein in children with acute respiratory infections and diarrheal diseases. Rev Saude Publica 1994;28(5):357-64.

19. Dudley L, Hussey G, Huskissen J, et al. Vitamin A status other risk factors and acute respiratory infection morbidity in children. S Afr Med J 1997;87(1):65-70.

20. Hanekom WA, Potgieter S, Hughes EJ, et al. Vitamin A status and therapy in childhood pulmonary tuberculosis. J Pediat 1997;131(6):925-7.

21. Kassu A, Andualem B, Van Nhien N, et al. Vitamin A deficiency in patients with diarrhea and HIV infection in Ethiopia. Asia Pac J Clin Nutr 2007;16(Suppl 1):323-8.

22. Qian L, Lu JR. Serum levels of IgG subclasses and vitamin A in children with recurrent respiratory tract infection. Zhongguo Dang Dai Er Ke Za Zhi 2007;9(6):557-8. 